\title{
Law, language, and knowledge: Legal transplants from a cultural perspective
}

\author{
Julio Carvalho*
}

(Received 26 January 2018; accepted 18 February 2018)

\begin{abstract}
In this Article, I have analyzed the philosophical grounds on which stands the conception of law implied in legal transplants. On the one hand, behind the idea of legal transplants lurks the misleading assumption that two different legal cultures share common epistemological accounts of what is meant by law; on the other, the idea that a certain legal institution verbally framed may be exported to another culture and touch off similar interpretations and conceptual performances reflects, at its core, a conception of language based on an isomorphic correspondence between legal words and the meanings those words are to stand for. My goal has been to critically expose the philosophical backdrop that lies behind the conception of law implied in the idea of a legal transplant with an eye to the cultural perspective. To this end, I have availed myself of different but convergent perspectives gathered from Wittgenstein's pragmatic philosophy of language, Geertz's cultural anthropology, Eco's semiology, Harris' integrational epistemology, and Rosen's cultural theory of law, as a methodological strategy to spotlight different facets of the problem in three dimensions: Language, knowledge, and law.
\end{abstract}

Keywords: language; philosophy of language; cultural anthropology; cultural theory of law

\section{A. Prolegomenon}

The fact that a same legal institution — a rule or legal concept—works quite differently depending on the cultural environment in which it is embedded displays a very enthralling phenomenon yet to be thoroughly elucidated in Legal Philosophy. Comparative legal studies may afford several examples of unsuccessful "legal transplants"1-the shift of a legal institution to different legal systems - which I shall not belabor here. Provided that a fair amount of writing on the occurrence of this phenomenon has already been produced, such as the well-known and opposing views of Alan Watson ${ }^{2}$ and Pierre Legrand, ${ }^{3}$ I will focus more precisely on why the discrepancies regarding the conceptual workings of a foreign legal element in the "receiving legal system" are closely linked to the cultural bedrock in which law is ultimately anchored.

The backdrop-question here is this: How is it possible to translate the legal-concepts-inpractice through which a legal culture is built to another world of meanings? The dissimilarity

\footnotetext{
*Julio Carvalho has completed Master of Laws (LL.M.) in Legal Theory, Goethe-Universität Frankfurt am Main, Law School, where he works as a doctoral researcher since March 2018. Email: juliocarvalho.adv@gmail.com

${ }^{1}$ See generally Mark Van Hoecke, Legal Culture and Legal Transplants, in LAW, SOCIETY AND COMMUNITY. SOCIO-LEGAL Essays In Honour of Roger Cotterrell 273-91 (Nobles Richard \& Schiff David eds., 2014).

${ }^{2}$ See generally Alan Watson, Legal Transplants: An Approach to Comparative Law (1993); Alan Watson, Comparative Law and Legal Change, 37 CAMBRIDGE L.J. 313 (1978).

${ }^{3}$ Pierre Legrand, The Impossibility of "Legal Transplants", 4 MaAstricht J. Eur. \& Comp. L. 111 (1997).
} 
in the conceptual behavior of the same legal institution in different social settings is a case in point that shifts the methodological prominence off the rule itself-and, to a larger extent, the idea of an "autonomous legal system-onto the deep-lying elements in which the functioning of law is grounded. This includes not only the social and historical contexts but also the all-embracing network of beliefs that holds institutional practices and social ways of life. The deep embeddedness of the law in a changeable social infrastructure affects, in ways which are yet to be thoroughly elucidated, how the law works at its most basic level.

Lawrence Rosen, in his book Law as Culture, proposed a very apposite question: "How much of the larger cultural context needs to be moved along with a legal feature for such a transplant to work?" My suspicion is that the borrowed legal element-a legal institution, a rule, or a concept-can only work uniformly in both settings, the borrower and the receiver, if one presupposes the same meaning frame. In other words, it must be presupposed a same underlying social epistemology for the network of sociolinguistic practices whereby legal institutions are used in a given culture. Within that purview, my aim is to explicate how the differences triggered in the conceptual behavior of the borrowed legal institutions spring directly from the cultural architecture in which they are entrenched. The hidden fallacy which I now set to unveil is to suppose that legal transplants of institutional constructs will display similar conceptual workings in the new legal environment.

Once legal institutions are decoupled from their original ground and resettled in different social emplacements, their intertextuality to the diffuse web of local practices will likely beget fundamental changes in their conceptual grammar. That is, they will be used according to different public criteria, for example, different cultural rules of signification. Gunther Teubner, translating legal transplants into the language of social systems theory, labeled them "legal irritants." In his paper on the transplantation of the continental principle of bona fides directly into the body of British contract law, he came to the same conclusion that "[f]oreign rules are irritants not only in relation to the domestic legal discourse itself but also in relation to the social discourse to which law is, under certain circumstances, closely coupled." In the last resort, a legal transfer "has to be assimilated to the deep structure of the new law, to the social world constructions that are unique to the different legal culture."6

The core of the misconception involving legal transplants is the ingenuous expectation that the shifting of legal institutions will haul along with them the whole background of conceptual practices historically developed in their original soil. Legal texts remain, however, tightly dependent on "a web of intertextuality, on [their] connection with stocks of knowledge and established practices of the city's residents." concerns. But before leading off with my subject, a caveat is worth making right at the outset: I won't probe empirical elements at length as I do not intend this paper to be a comparative study in itself. The methodological procedure I shall pursue is predominantly theoretical. My goal is to

\footnotetext{
${ }^{4}$ Lawrence Rosen, Law As Culture: An Invitation 42 (2006).

${ }^{5}$ Gunther Teubner, Legal Irritants: How Unifying Law Ends up in New Divergences, in VARIETIES OF CAPITALISM: The Institutional Foundations of Comparative AdVAntage 441 (Peter A. Hall \& David Soskice eds., 2001). In this paper, wherein Gunther Teubner analyses the transplantation of the continental principle of bona fides directly into the body of British contract law via the European Consumer Protection Directive 1994, he states at 418: "Legal institutions cannot be easily moved from one context to another, like the 'transfer' of a part from one machine into another (Kahn-Freund 1978). They need careful implantation and cultivation in the new environment. But 'transplant' creates the wrong impression that after a difficult surgical operation the transferred material will remain identical with itself, playing its old role in the new organism." According to the author, at 418: "Legal irritants cannot be domesticated, they are not transformed from something alien into something familiar, not adapted to a new cultural context, rather they will unleash an evolutionary dynamics in which the external rule's meaning will be reconstructed and the internal context will undergo fundamental change."

${ }^{6} I d$. at 426.

${ }^{7}$ Thomas Vesting, Preface to the Brazilian edition of TeOria do Direito: Uma INTrodução 19 (2015).
} 
expose the philosophical underpinnings, concerning both the language and the knowledge, that lie behind the conception of law implied in the idea of a successful legal transplant with an eye to the cultural perspective.

The first notion I must lay bare in these initial paragraphs suggests how language and culture rope together. Humans are endowed with the remarkable capacity to create the categories of their own experiences. ${ }^{8}$ This capacity to collectively conceptualize, work out, and recreate our common experiences is called culture; ${ }^{9}$ that is what makes it possible for people to collectively inhabit a same world of meanings and share common experiences, values, ideas, and knowledge about the surrounding reality. Moreover, that is what gives us the sense of what is real, what makes us feel at home in the reality we take to know of. Since the late Wittgenstein, it remained clear that it is not the structure of reality that shapes the logical structure of language by isomorphic correspondence, but it is the structure of language-its conceptual apparatus - that configures what we think of as reality and how we act upon it. Languages are conjugate practices tightly amalgamated with other social practices, as inherited techniques, applied and exercised in familiar practices and shared language-games ${ }^{10}$.

Any serious take on language may not leave unnoticed this hallmark: It is a collective enterprise in its bent, a cultural, social, and public affair ${ }^{11}$ par excellence; it cannot be narrowed down to a mere concatenation of speech acts. As Vesting argued in Die Medien des Rechts, every speaker is embedded in the language while the language articulates itself in the speaker as a whole larger than the sum of its parts. ${ }^{12}$ Under a semiotic profile, Umberto Eco shares a similar view drawn from a metaphorical representation of language as a "social treasury," encompassing not only a range of grammatical rules and lexicographical definitions but also the whole cultural encyclopedia that the performances of a language have generated. ${ }^{13}$ The uses of our languages are always tied up with a network of cultural knowledge and traditions atavistically accrued. ${ }^{14}$

These remarks, that I shall spell out right in the beginning of my enterprise, are necessary to explicate how law, language, and culture interlock. In comparative law, it is commonly held that one does not learn about a foreign law by studying its legal vocabulary; ${ }^{15}$ instead, it is necessary to get at the structures underpinning the systems of legal thought. ${ }^{16}$ Lawrence Rosen well framed the issue: When a court employs terms such as "the conscience of the community," "the reasonable man," or "the clear meaning of the statute," "the meaning of these concepts will come not just from the experience of legal officials or some inner propulsion of the law but from those broader assumptions, reinforced across numerous domains, that characterize the culture of which law is part." ${ }^{17}$ As Vesting put it, "a judge has to, a priori, speak an idiom and inhabit a semantic world to interpret a legal text." ${ }^{18}$ Even Luhmann's social system theory approach could not cast aside the

\footnotetext{
${ }^{8}$ Rosen, supra note 4 , at 3.

${ }^{9} I d$. at 4 .

${ }^{10}$ G.P. Baker \& P.M.S. Hacker, Wittgenstein: Rules, Grammar and Necessity: Vol. II of An Analytical Commentary on the Philosophical Investigation, Essays and Exegesis of $\$ \$ 185-242$. Vol. II, 224 (2d ed. 2009 ).

${ }^{11}$ Thomas Vesting, Die Medien des Rechts: Sprache 47 (2011).

${ }^{12}$ See id. at 48.

${ }^{13}$ See Umberto Eco, Confessions of a Young Novelist 42 (2011).

${ }^{14}$ See Vesting, supra note 11, at 52 („Praktisch gesehen schließt der sprachliche Zeichengebrauch daher immer an einen Bestand bereits überlieferter Informationen und Traditionen an, er erfolgt stets in bestimmten Bahnen oder ,Trajektorien', sonst wäre Kollektives Lern undenkbar und alle kulturelle Evolution ein unerklärliches Mirakel.“)

${ }^{15}$ Louise Rayar, Conference Paper, Translating Legal Texts: A Methodology, 5 (1993), in GeOfFrey SAMUEL, EPISTEMOLOGY AND METHOD IN LAW 40 (2003).

${ }^{16}$ Geoffrey Samuel, Epistemology and Method in Law 40 (2003).

${ }^{17}$ Rosen, supra note 4, at 6-7.

${ }^{18}$ Thomas Vesting, O Direito Moderno e a Crise do Conhecimento Comum, in CADERNOs FGV DiReITO RIO, VOL. I. TEORIAS Contemporâneas do Direito: o Direito e as Incertezas Normativas 29 (Pedro Fortes, Ricardo Campos \& Samuel Barbosa eds., 2017).
} 
rudimentary notion that "law is after all a part of society's language, as are all scientific languages, embedded as they are in common language." 19 In the case of law, on the one hand, it is by articulating and reproducing an institutional reality couched in the tissue of language that a world of meanings and a sociocultural framework are naturalized as existing things far beyond the physical reality of the palpable world. On the other hand, it is linguistically partaking in a socialized epistemology of a pre-existing working language that law is set in place as an intelligible social artifact for a given culture. To come straight to the point, law is partly a constructive element of a culture and partly an emergent property of a cultural infrastructure. ${ }^{20}$

A second workable hypothesis is that behind the idea of "legal transplants" —or "legal borrowing"-lurks the misleading assumption that two different legal cultures share common epistemological accounts of what is meant by law, ${ }^{21}$ and, by extension, its institutional elements - as though law were amenable to be aseptically represented as a systemic array of objective meanings rationally determined and logically derived from legal texts through a value-free and context-independent interpretative process. In view of this, my second task is to foreground how knowledge does not simply crop up in a vacuum. The production and the shared practices of knowledge take place necessarily somewhere, between some people and at some time. It may strike as a truism to think of knowledge as something fixed and absolute, a damnosa hereditas left by Plato. But what I shall argue is exactly the opposite: Knowledge is not a cognitive relation established between a knowing subject and an object, but a form of activity that presupposes ways of doing things - methods, procedures, rules, or tradition. The sort of epistemology to which I subscribe falls foul of a theory of knowledge "without a knowing subject" 22 and fully embraces an integrational methodology.

In the third and last part, so imbued with the right angle on both language and knowledge, I will readdress the theoretical problem of the law initially formulated. Here, my account, insofar as it places the human activity at the center of law's ontology, automatically dissent from: (a) epistemic models, such as Kelsen's pure theory of legal ontology (grounded in a logic-transcendental metanorm); and (b) metaphysical models that quest for an essentialist definition of law. Law, from this angle, is a label we conventionally attach to a range of institutional practices socio-historically situated with an "open plot" to human activity. The positivity of the law is not something that simply "is" (an object), but "a work in progress" (a process) tightly bound up with a sociocultural structure holding a sway over the concept of law. As Vesting broached in his book Rechtstheorie, "answering the question of whether and, if so, in which way it at all still makes sense to speak of a specific 'validity' or a 'normativity' of law, is certainly one of the great challenges of contemporary Legal Theory." ${ }^{23}$ By the end of this digression, I hope my efforts will leave a sense of an approximation to that question.

At last, one honest caveat is apposite as a measure of academic etiquette and methodological exemption: Occasional references to one thinker or another should not be interpreted as a wholesale embracement of his or her whole corpus of ideas. The exploratory method underlying these lines grants me the possibility of probing workable points of theoretical tangency with this or that

\footnotetext{
${ }^{19}$ Niklas Luhmann, LaW as a Social System 125 (Klaus A. Ziegert trans., 2004) But Luhmann's account departs from that statement to sustain, after, that "[ $\mathrm{t}]$ he unfolding of the tautology 'law is valid law' by a distinction of several levels of regulation is grounded on the fact of social differentiation, that is, the differentiation of the legal system from within the social system." Such a normative demarcation of the linguistic boundaries of the social systems will not be endorsed in this text.

${ }^{20}$ Clifford Geertz, Off Echoes: Some Comments on Anthropology and Law, 19 Pol. \& Legal ANThropology Rev. 33,35 (1996), in Rosen, supra note 4, at 8.

${ }^{21}$ See Geoffrey Samuel, Epistemology and Comparative Law, in EPISTEMOlOGY AND Methodology of Comparative LAW 61 (Mark Van Hoeck ed. 2004).

${ }^{22}$ Karl R. Popper, Objective Knowledge: An Evolutionary Approach 106 et seq. (1974).

${ }^{23}$ Thomas Vesting, Rechtstheorie: EIN STUdiEnbuch 115 (2015) („Die Frage zu beantworten, ob und wenn ja, auf welche Weise es heute überhaupt noch Sinn macht und gegebenenfalls Sinn machen könnte, von einer spezifischen "Geltung" oder „Normativität“ des Rechts zu sprechen, ist sicherlich eine der größten Herausforderungen der gegenwärtigen Rechstheorie.").
} 
author whichever their philosophical backgrounds might be. First and foremost, I am neither in the business of creating a theory of law ex nihilo, nor of merely emulating the terra firma of the mainstream. Rather, I am doing legal theory as an authentic reflective activity on the footing of well-established scholarly trains of thought; for while my principal concern I deem to be fairly outlined, I shall use theoretical components from different families of theories to spotlight different facets of the same object. Piecing these theories together as an eclectic approach to show the problem in its best light will be my main theoretical dare.

\section{B. Language}

\section{Initial remarks}

In light of the theoretical problems raised in my opening lines, my aim throughout this Section is to lengthily analyze the deep-seated interplay between law and cultural environment. The first step in the long walk through the torrid themes of law, language, and culture, as advanced in my prefatory remarks, can only begin with a fair survey of language in its connection with institutions and culture. If culture "is the stitching together across domains of the categories of experience and the relationships that are connected to them" 24 and law is fundamentally couched in the common language of a cultural system, then a sound and thorough account of language is central for a cultural theory of law. In broad terms, what I shall do in this Section is to expound a pragmatic theory of language as a fundamental step towards a successful cultural take on law. The focal point that I will try to put across along these lines is that culture permeates the totality of our social interactions as it forges the frames of signification for social life. This is the key aspect of how we grasp social occurrences and how we act upon the structures of institutional practices. At the core of our social imagery-our capacity to represent fragments of reality and states of affairs-lies the cultural framework within which institutions function and shape the social world, "each culture fashioning a baseline from which, out of the totality of sense and imagination, a believable way of grasping facts can be forged." 25

\section{Institutional ontology and "seeing as"}

Unlike physical objects, institutions (e.g., property, governments, money, or law) require language for their existence. As Searle rightly remarked in The Construction of Social Reality: "Symbols do not create cats and dogs and evening stars; they create only the possibility of referring to cats, dogs, and evening stars in a publicly accessible way." ${ }^{26}$ Contrariwise, language is essentially constitutive of institutional reality. ${ }^{27}$ As a matter of conceptual necessity, it is the fabric of language, tied to its underpinning structure of shared practices, that sews through and through our social world. Likewise, as Hart remarked in The Concept of Law, we lawyers stand in the realm of fiction. "It is only because we adopt this fiction that we can talk solemnly of the government of laws not men." 28

It is perfectly possible to imagine a society with rudimental linguistic apparatus void of the whole institutional paraphernalia we are accustomed to-governments, private property, corporations, civil and social rights, and so on. As very well put by Searle, it is quite hard to imagine a society that comprises these institutional structures but is devoid of any symbolic medium of representation. ${ }^{29}$ Searle's route, however, to explain the institutional ontology within societies sets out from

\footnotetext{
${ }^{24}$ Rosen, supra note 4 , at 67.

${ }^{25} I d$. at 11 .

${ }^{26}$ John Searle, The Construction of Social Reality 75 (1995).

${ }^{27} I d$. at 59; John SEArle, MaKing the Social World 63 (2010).

${ }^{28}$ H.L.A HART, The CONCEPT OF LAW 12 (2d ed. 1997).

${ }^{29}$ John Searle, Making the Social World 62 (2010).
} 
collective mental phenomena towards a taxonomy of logical forms of speech acts-for which he claims a specific philosophical branch ("The Philosophy of Society" ${ }^{30}$ ), an academic discipline of social ontology grounded in physicalism. In brief, his philosophical efforts are focused on knitting together mental phenomena (biology), language (speech acts), and society (social institutions).

Here is where the philosophical methodology I shall follow in this text part company with his institutional theory. Whereas his account of language is vastly naturalistic, holding that "human reality is a natural outgrowth of more fundamental-physical, chemical, and biologicalphenomena," 31 my investigations into language and social reality not only take a different outset but also walk a different path. Concerning the analysis of language, my scrutiny is not confined to the narrow scope of speech acts, but the perception of language as a living cultural organism-a second nature which spills over the boundaries of a mere juxtaposition of individual speech units. In this connection, institutional ontology cannot be spellled out solely on the basis of a hidden logical structure underlying certain speech acts.

As Searle himself conceded in Making the Social World, institutional facts "are without exception constituted by language, but the functioning of language is especially hard to see." 32 Wittgenstein was perhaps the first to forewarn this philosophical ambush: "We want to understand something that is already in plain view [language]. For this is what we seem in some sense not to understand." ${ }^{33}$ In contradistinction to Searle's biosocial philosophy, ${ }^{34}$ the kernel of my concerns is the cultural pragmatics of the functioning of language and how it relates to the workings of legal institutions in the social world. My task, as advanced in the introduction, will be to scrutinize how law, language, and culture rope together.

Despite these methodological contrasts, Searle offers a very illustrative example of how we need language to see institutional facts and this might be a good starting point to belabor. Indeed, without language, we can perfectly see a man cross a white line holding a ball, but we cannot see the man score six points, nor do we want him to score six points ${ }^{35}$. Without a conceptual framework provided by our language, we would not be able to see this event as a goal or a point in a game, for these institutional entities - goal and game-require some linguistic apparatus underpinned by a collective intentionality - a bundle of social beliefs and attitudes underwriting "their existence"in order to exist in the social world.

Searle's illustration resembles Wittgenstein's ambiguous image of the duck-rabbit in Philosophical Investigations, drawing our attention to the "aspect seeing" (Gestalt) phenomenon. In this philosophical experiment, Wittgenstein proposes an ambivalent picture which can be seen either as a duck or as a rabbit, hinting that our capacity to "aspect-seeing" hinges on the ample network of concepts, experiences, and background knowledge, which we have incrementally developed in our own linguistic praxis. A woman who is very fond of Bordeaux's finest wines

\footnotetext{
${ }^{30} I d$. at 5.

${ }^{31} I d$. at 61 .

${ }^{32} I d$. at 90 (emphasis added) ("We live in a sea of human institutional facts. Much of this is invisible to us. Just as it is hard for the fish to see the water in which they swim, so it is hard for us to see the institutionality in which we swim. Institutional facts are without exception constituted by language, but the functioning of language is especially hard to see .... What I mean is that we are not conscious of the role of language in constituting social reality.").

${ }^{33}$ Ludwig Wittgenstein, Philosophical Investigations 47e, $\$ 89$ (G. E. M. Anscombe, P. M. S. Hacker \& Joachim Schulte trans., 2009).

${ }^{34}$ SEARLE, supra note 26, at 9 ("Historically in our intellectual tradition we make great distinctions between mind and body and between nature and culture. In the section on Fundamental Ontology, I tacitly abandoned the traditional dualistic conception of the relation of mind and body in favor of the view that the mind is just a set of higher-level features of the brain, a set of features that are at once 'mental' and 'physical.' We will use the 'mental,' so construed, to show how 'culture' is constructed out of 'nature."').

${ }^{35} \mathrm{Id}$. at 68 (emphasis added) ("Without language, we can see the man cross a white line holding ball, and without language we can want a man to cross a white line holding a ball. But we cannot see the man score six points or want the man to score six points without language, because points are not something that can be thought of or that can exist independently of words or other sorts of markers. And what is true of points in games is true of money, governments, private property, etc.").
} 
and an assiduous reader of Proust's, Flaubert's, and Balzac's great novels will see the boulevards and the streets of Paris in a very different light in comparison with any other person bereft of such background. ${ }^{36}$ On a gripping quote from La Rochefoucauld, Searle observed that "very few people would fall in love if they never read about it; and nowadays, we would have to add if they never saw it on television or in the movies." 37 Despite the different nuances one may experience in the semantic relation with certain words, the common process of deep socialization in a form of life embeds the individuum in shared social experiences, in a common atmosphere that is formed around common uses of a language.

Our experiences of meaning come to us bound up with the conceptual apparatus and the social imagery we have culturally developed in the totality of language games in which we were trained. The "nature of things, concepts, the uses of words and grammar are inextricably interwoven." 38 Wittgenstein's opening aphorism in Culture and Value may exemplify the point: "Someone who understands Chinese will recognize language in what he hears. Similarly I often cannot discern the humanity in a man." 39 His own italicization points to the conclusion that we use conceptual frameworks (e.g. language, humanity) to cope with the world, to see the world beyond raw sensory data. The central argument I want to stress is this: There is no Archimedean foothold outside the ground-floor web of language games and forms of life-in which we are inexorably enmeshed-from where we could see things and appraise world's occurrences.

The hermeneutics behind the philosophical experience of seeing-as spills over the edges of a sheer refinement of linguistic pragmatics. It knocks down "our inclination to think of perceptions in terms of the influence of objects on a receptive faculty, and draws our attention to the role of an active, responding subject in determining the nature of visual experience, or in fixing what is seen." ${ }^{\prime 4}$ Moreover, it holds a key notion for understanding how we see things by aspects or facets in socially informed ways and how we use the conceptual schemata of language as a toolbox to configure the ontological categories of the social world. ${ }^{41}$

\section{The two Wittgensteinian perspectives on language and further semiotic, anthropological, and epistemological investigations}

Since I am already on Wittgensteinian grounds, it might be opportune to backtrack a little and burrow down the implications of Wittgenstein's philosophy at appropriate depths. The pragmatic turn prompted by the mature Wittgenstein marked a philosophical turnabout in the relation between language and the social world, bringing to a grinding halt the preceding logical trend. In the Tractatus Logico-Philosophicus (1921), Wittgenstein was mainly concerned with the analytical work of logical clarification of sentences of a natural language. His premise was that, if sentences were able to mean something, then pieces of reality would be amenable to be pictured by a logical structure that could make such representation (correspondence) possible. There, he argued for a logical isomorphism between bits of reality and the hidden syntactical structure of language. Propositions could be understood in terms of logical pictures: They could depict the world and agree with reality, in which case they would be true; or not, in which case they would be false. Language could "fit" the world it portrayed in a very direct manner.

Although the main lines of the Tractatus were disowned by the older Wittgenstein, he was at this juncture deeply committed to the philosophical task of revealing the conditions of possibility of an accurate representation of reality by means of a logical proposition. He wanted to deliver a

\footnotetext{
${ }^{36}$ See also id. at 135 (providing a similar example).

${ }^{37} I d$.

${ }^{38}$ BAKER \& HACKER, supra note 10 , at 56.

${ }^{39}$ Ludwig Wittgenstein, Culture and Value 1e (Peter Winch trans., 1984).

${ }^{40}$ Marie Mcginn, Wittgenstein and the Philosophical InVestigations 195 (1997) (emphasis added).

${ }^{41}$ See Donald K. Barry, Forms of Life and Following Rules: A WitTgensteinian Defense of Relativism 68 (1996) (emphasis added).
} 
very clean black and white philosophy of language that could trace through and through how thoughts, language, and the world related to each other, purging the philosophical climate of the metaphysical deadlock in which it was trapped. Along the lines of the Cambridge School of Analysis and the Vienna Circle, language was not construed as a social practice in its natural bent, but a logical macrostructure, a jigsaw puzzle with jumbled pieces (propositions) to be logically tidied up by the hands and minds of trained logicians and mathematicians.

A contradistinction, though, separates the first Wittgenstein from other philosophers in the logical tradition: Whereas his close predecessors, Russell and Frege, were engaged in devising an ideal logical notation to treat the logical defects of ordinary language, ${ }^{42}$ Wittgenstein was convinced that the logical treatment of ordinary language was rather a matter of bringing to light what was lurked in the syntactical infrastructure of the symbolism of a language. ${ }^{43}$ Enshrined at the heart of the Tractatus, the pictorial theory of meaning propounded the idea that in order for propositions to mean something accurately, a logical symmetry between them and the state of affairs they purported to depict had to be at work.

But if the Tractarian perspective was focused on refining and cleansing ordinary language to unfold the logical structures lurked under the surface grammar, the older Wittgenstein backpedaled on his main lines of thought and gainsaid the central theses he previously advocated. His Philosophical Investigations ${ }^{44}$ radically overturned the relation between language and reality, dislodging the direction of fit between these two. Instead of excavating the surface grammar of the ordinary language to unearth the underlying syntactical structure under the premise that they could mirror states of affairs with indefectible precision, the second Wittgenstein embraced the idea that language works rather as a toolbox configuring, not picturing, what passes as reality. Moreover, it is a public affair, a social art deeply associated with the morass of complex overlapping practices in which we are enmeshed. Languages do not hang on theories to function. They are carried out by human practices and, in great measure, independent of any logical accountability. The positivistic take on language was shored up by two philosophical theses I shall put on display and demystify all at once: On the one hand, the epistemological assumption of a one-to-one language-world relation of objective correspondence between logical propositions and non-linguistic entities (to be disclosed by means of logical analysis); on the other hand, a presupposition of a mind-language relation which came to be coined, in the technical jargon of philosophy, as the telementational conception of language.

At the core of the first premise - the language-world relation-lies the problem of incommensurability between the structure of reality and the structure of language. Roy Harris immediately stands out as one of the most prominent scholars who addressed this predicament in this celebrated book The Language Myth ${ }^{45}$ One of the key points he broached touches on the philosophical awkwardness of collating two contrasting ontological categories, language - a verbal report-and a fact of the external world - a non-linguistic structure-in terms of logical correspondence. As Gilbert Ryle himself once intimated: "I cannot myself credit what seems to be the doctrine of Wittgenstein [the first] and the school of logical grammarians who owe allegiance to

\footnotetext{
${ }^{42}$ See P. M. S. Hacker \& G. P. Baker, Language, Sense and Nonsense: A Critical Investigation into Modern Theories OF LANGUAGE 25 et seq. (1986). For Frege, natural language was "rife with vagueness, ambiguity, lack of logical perspicuity, and, indeed, logical incoherence. To a large degree he identified as 'logical defects' in a language those features of it which fail to correspond with the articulations of his concept-script .... The old idea of isomorphism between a form of representation and thought or reality was, however, resuscitated by the invention of a much improved logical calculus. This idea too was to bear fruit in the next stage in this history. It is noteworthy that the invention of powerful formal calculi gave impetus to the 'biplanar' or Augustinian conception of language .... This became even clearer in the reflections of Russel, who pursued further Frege's vision of reducing arithmetic to logic, and who developed further the formal apparatus of a rich function-theoretic calculus."

${ }^{43}$ See id. at 39.

${ }^{44}$ See WitTgEnstein, supra note 33.

${ }^{45}$ See Roy Harris, The Language Myth 27 et seq. (1981).
} 
him, that what makes an expression formally proper to a fact is some real and non-conventional one-one picturing relation between the composition of the expression and that of the fact." 46

The main target of both Harris' and Ryle's criticisms here is the relation of "property" between facts or states of affairs and logical forms. As Harris claims, "it is entirely obscure how we are to make sense of the notion that reality has structures which are compatible to structures of the kind relevant to verbal analysis." ${ }^{47}$ At bottom, what is under attack here is not a certain theory of language, but a certain conception of language, a framework of thought, a myth, if you will, that there is a direct and fixed relation between language-names - and reality - things or nonlinguistic entities for which words serve as names. When Wittgenstein deserted the Tractarian thesis of a word-world logical nexus - the Augustinian conception-and embraced the thesis that language works rather in use, that is, as a constitutive tool of the form of life and culture of its users, it was not a particular theory of language that was called into question, but a whole conception of what language de facto is. This philosophical reorientation cannot be trivialized, for it had a profound impact on our understanding of the very ontological relation between language and reality. There is no isomorphism between language and reality. ${ }^{48}$ This does not mean, as Backer and Hacker remarked, that we cannot refer to things "in reality" when we use words, but simply that the meaning of a word is not a thing or an entity, ${ }^{49}$ but the way in which it is put into practice. On this picture, there is no connection between language and reality in the Tractarian sense, for language works rather as a "free-floating structure" with an autonomous grammar. ${ }^{50}$

Another insurmountable methodological hurdle that seems to be the Achilles' heel in the epistemological premise behind the positivistic project is that the basic work material at the disposal of philosophers and mathematicians engaged in logical positivism is the language itself. Roy Harris admitted this problem by saying that any attempt at reflecting analytically upon this process of creative renewal called language is at the mercy of words. And words, the product of that very process, rather obscures the process of analytical reflection itself. ${ }^{51}$ This is the Archimedean predicament any language-bound theorist must face: He, "like the earth-bound Archimedes, has nowhere else to stand but where he does. He has ultimately no leverage to bring to bear on understanding language other than such leverage can be exerted from the terra firma of his own linguistic experience." 52

"We are struggling with language. We are engaged in a struggle with language," said Wittgenstein. ${ }^{53}$ As of his later philosophy, he ultimately came to the view that, as a languagebound thinker, he could not help being entangled in a struggle against the bewitchment of our understanding by the resources of our own language. ${ }^{54}$ This is an intractable philosophical hurdle that persists to this day in the traditional epistemology, for it "comes to be in the curious position of always having to pull itself up by its own linguistic bootstraps." ${ }^{55}$ As Harris provocatively said in After Epistemology, there is no such thing as "languageless epistemology." 56 The epistemologist, as

\footnotetext{
${ }^{46}$ Gilbert Ryle, Systematically Misleading Expressions, in LogiC LANE: ColleCted Essays 1929-1968, VOL. 2, at 62 (2009).

${ }^{47}$ HARRIS, supra note 45 , at 27.

${ }^{48}$ See G.P. BAKer \& P.M.S. Hacker, Wittgenstein: Understanding and Learning: Vol. 1 OF An AnAlytical Commentary on the Philosophical Investigations, Part I: Essays, at 16-17 (2d ed. 2009).

${ }^{49} I d$. at 16.

${ }^{50} I d$. at 16 .

${ }^{51}$ HARRIS, supra note 45, at 1 ("Our attempts to understand language seem to be at the mercy of words, but words are designed primarily for purposes other than that. Here straight away, it might seem, we see lucidly identified for us one of the main sources of the difficulties which threaten to thwart whatever attempts man make to reflect analytically upon this process of creative renewal which is language. Words, the product of that process, obscures the process itself.").

${ }^{52} I d$. at 204.

${ }^{53}$ WiTtGenstein, supra note 39 , at $11 \mathrm{e}$.

${ }^{54}$ Ludwig Wittgenstein, Philosophy of Psychology-A fragment vi, in Philosophical Investigations, supra note 33, at $52 \mathrm{e}, \S 109$.

${ }^{55}$ Roy Harris, After Epistemology 8 (2009).

${ }^{56} I d$.
} 
much as the linguistic theorist, has no other choice but to come to terms with the fact that words partake of the daunting quality of being cultural facts, metalinguistic posits and conceptual tools all at once. ${ }^{57}$

The other premise espoused by the telementational conception of language is a longestablished thesis regarding the mind-language relation, according to which words are ciphers of a code that we use to encapsulate our thoughts and put them across clearly and effectively. A hypothetical user of the same code would thus be able to decode these syntactical units and unfold the communicated meaning. The underlying idea of this doctrine is that, forasmuch as we succeed in our day-to-day lingual transactions, a "fixed code" has to be at work. Hacker and Baker both situate the telementational thesis within the post-Cartesian tradition, while other scholars like Roy Harris trace this conception back to Aristotle's De Intepretatione ${ }^{58}$ and Plato and Socrates' "classical model of language." ${ }^{59}$ But the basic idea under the label is the conception of language as being nothing more than a vehicle for transmission of thoughts (telementation). ${ }^{60}$ This doctrine, embraced by philosophers such as Hobbes and Locke in modern times, held a considerable sway over a great deal of the nineteenth and twentieth-century philosophical reflection, even encroaching upon the domains of theoretical linguistics.

When Wittgenstein put the doctrine of telementation, under the label "Augustine's picture of language," into a checkmate right at the outset of his Philosophical Investigations, he marked there and then a clean break with the whole logical tradition and the classical model of language ${ }^{61}$. The main point of attack raised by him and like-minded scholars is that the myth of telementation entails an external semantics between thought and language and, by extension, between language and nonlinguistic entities. To be precise: On the one hand, thoughts would be conceived as a languageindependent mental process for which language would serve as a public code (a logical system of signs) into which thoughts (as a neurophysiological process) could be translated and neutrally communicated to another common user of the code. On the other hand, words could only mean insofar as they correlated to-or stood for-non-linguistic units in an ostensive manner.

But a theoretical trap lurked in the telementational thesis. Language is a common resource for social communication, a public storehouse of semiotic assets. Not rarely people find themselves, in the ordinary usage of it, embroiled in a communicational misjudgment and have to spell out what they meant to say to the other. The idea of a telementation presupposes that the meaning one puts across with a word is exactly the same as the meaning that the other speech player associates with it. But the fact remains that, as Wittgenstein warned: "[I]f the possible uses of a word are before our minds in half-tones as we say or hear it-this goes just for us. But we communicate with other people without knowing whether they have these experiences too." ${ }^{2}$ Telementation leaves out the recurrent phenomenon of unintended results in the use of language. It disregards the fact that the semantics of a word is not conditioned by a dictionary, but by a complex cultural encyclopedia.

What is more, the detachment of thought from language delivers an empiricist riddle to be puzzled out, given the self-evidence in our linguistic routine that we can only come to be in touch with our own thoughts, so to speak, in semiotic terms. Wittgenstein, in his preliminary studies for

\footnotetext{
${ }^{57}$ Roy Harris, Language, Saussure and Wittgenstein: How to Play Games with Words 126 (1988) (“Words are at the same time cultural facts, metalinguistic posits and conceptual tools. Hence to draw the empirical/non-empirical distinction for discourse about language within the framework of that paradigm [of science] becomes intrinsically problematic. It involves the paradoxical enterprise of trying to go beyond and yet keep within the limits of language.").

${ }^{58}$ Aristotle, De Interpretatione, in The BASIC WORKS OF ARISTOTLE 40 (Richard McKeon ed., 2001) ("Spoken words are the symbols of mental experience and written words are the symbols of spoken words. Just as all men have not the same writing, so all men have not the same speech sounds, but the mental experiences, which these directly symbolize, are the same for all, as also are those things of which our experiences are the images.").

${ }^{59}$ See HARRIS, supra note 55, at 11 et seq.

${ }^{60}$ See HACKER \& BAKER, supra note 42 , at 17 et seq.

${ }^{61}$ WitTGENSTEIN, supra note 53 , at $5 \$ 1$.

${ }^{62} I d$. at $190 \mathrm{e} \S 35$.
} 
Philosophical Investigations (The Blue and Brown Books), already addressed how misleading it is "to talk of thinking as of a 'mental activity.' We may say that thinking is essentially the activity of operating with signs." ${ }^{63}$ There he assessed inter alia the mental experience of groping for a word while writing a letter and analyzed the grammar of the clause "to express an idea which is before our mind." Of course, it is a metaphor, but it reflects the commonsensical fallacy that we would be, as it were, endeavoring to put into words what was already mentally expressed-a translation of mental language into verbal language. In his own disclosure: "I have been trying in all this to remove the temptation to think that there 'must be' what is called a mental process of thinking, hoping, wishing, believing, etc., independent of the process of expressing a thought, a hope, a wish, etc." ${ }^{4}$ Taken to the extreme, it seems in effect odd how could we be able to reason, at least theoretically, in a "semiotic vacuum." The most plausible way out of this blind alley seems to point into the opposite direction: It is language, this semiotic patrimony on which we stand to evolve historically, that sways our thoughts-and knowledge in the last resort.

In hindsight, Wittgenstein's late works might be very well pieced together as a philosophy of culture. ${ }^{65}$ His linguistic pragmatism ultimately brought down the house of cards of logical skepticism by showing how one cannot talk about signs of a language beyond the boundaries of a culture, wherein the very process of signification takes place. At the end of the day, Wittgenstein's cultural philosophy discredits altogether the possibility of a universal pre-cultural language by suggesting, instead, a diachronic philosophical grammar for the language. "[We are] talking about the spatial and temporal phenomenon of language, not about some non-spatial, atemporal non-entity." 66 If logical positivists were professionally engaged in demarcating, by means of logical analysis, the limits of language-pinpointing where the sense ends and the nonsense begins, what could be meaningfully said and whereof one could not speak-the pragmatic turn made clear that such demarcation depends to a great extent on the sort of education we had and on the unquestioned framework of ideas which we have been trained to accept. ${ }^{67}$ The language myth, grounded in two deep-rooted beliefs about what language stands for-the doctrine of telementation and the doctrine of the fixed code, as Roy Harris described them-is in itself a cultural construct; or, to use Harris' words, "a cultural fossil that has gone unchallenged for so long that it has hardened into a kind of intellectual concrete." 68

The interpretative process of comprehension of signs, and of language itself, is essentially a cultural process. We wouldn't be able to communicate nor to understand the meaning of a single semiotic mark outside of the web of significant associations called culture. Wittgenstein hinted this point by saying: "Every sign by itself seems dead. What gives it life?-In use it lives." 69 The key concept of language-game, meaning "the whole"70 in which language and human praxis intermesh, was methodologically used to shift the emphasis onto how language is not outright part of a cognitive relation, but of a cultural process in the first place. Wittgenstein's cultural pragmatics, in the last resort, resets the internal semantics between signs and their cultural uses. Delving deeper into Wittgenstein's late writings, what the Austrian philosopher unveils is a conception of signs consonant with what Roy Harris and other like-minded scholars have termed "integrationist semiology," in accordance with which the idea of a decontextualized sign finds

\footnotetext{
${ }^{63}$ Ludwig Wittgenstein, The Blue and Brown Books: Preliminary Studies for the Philosophical Investigations 6 (1965).

${ }^{64} I d$. at 41 .

${ }^{65}$ See Stanley Cavell, Declining Decline: Wittgenstein As a Philosopher of Culture, in Stanley Cavell, This New Yet UnAPProachable AMERICA: LeCtURES AFTer EMERSON AFTER WitTGENSTEIN (1989).

${ }^{66}$ WitTGENSTEIN, supra note 33 , at 52e, $\$ 108$.

${ }^{67}$ HACKER \& BAKER, supra note 42 , at $12-13$.

${ }^{68}$ Roy Harris, The Role of the Language Myth in the Western Cultural Tradition, in THE LANGUAGE MYTH IN WESTERN Culture 1 (Roy Harris ed., 2013).

${ }^{69}$ WitTGENSTEIN, supra note 33 , at $135 \mathrm{e}, \S 432$.

${ }^{70} I d$. at $8 \mathrm{e}, \S 7$.
} 
no ground at all. Signs only exist as such in the particular circumstances in which they function or are used as signs. That is, a sign only means something inside the process of a culture. In a world without a culture, there would not exist any sign. ${ }^{71}$

This internal proto-semantics between signs and culture is interestingly highlighted by Karl-Heinz Ladeur in Die Textualität des Rechts, wherein he approaches inter alia how the readings and the readers themselves of a novel are both constituted inside and by a culture. ${ }^{72}$ The readings of a novel produced inside a culture are greatly interlocked with previous readings that helped to form that culture. Likewise, Umberto Eco, in Confessions of a Young Novelist, used the conceptual metaphor of "social treasury" to spotlight how language does not comport with a dictionary-like representation. It rather incorporates the whole encyclopedia of linguistic performances, cultural conventions, and the history of previous interpretations of its many texts. ${ }^{73}$ According to Eco, "the world knowledge provided by an encyclopedia has nothing to do with our direct, physical, and frequently idiosyncratic experience of the world; it has on the contrary to do with other semiotic phenomena, with intertextual knowledge, with a chain of interpretants."74

On anthropological grounds, Clifford Geertz also espoused a semiotic concept of culture in his book The Interpretation of Cultures. It is worth noticing how Eco's semiotics and Geertz's cultural analysis both share a common space between semiology and anthropology. For Eco, on the one hand, the laws of signification are the laws of culture, ${ }^{75}$ for Geertz, on the other, culture comprises the socially established structures of meaning in terms of which people inter-act in a conjoined semiotic conspiracy. The members of a culture are internally trained to recognize these signs, to act upon them, and to use them in their daily business. A culture, therefore, can be analyzed as interworked systems of construable signs — or symbols such as words, gestures, images, etc.- - for which a methodology of cultural analysis should orient the ethnographic interpretation of the social discourse, including the symbolic actions, practiced in a semiotic community by sorting out the underlying structures of signification. ${ }^{76}$

Another interesting similarity between Eco's encyclopedia and Geertz's concept of culture is that both account for the capacity of culture for semiotic accruement. As Karl Eibl accentuates in Animal Poeta, Geertz's image of culture as a meaning-fabric provides the right sense of a symbolic-communicative process in the evolution of men. It was only on the footing of semiotic resources that the storage of cultural inventories, information, and rules was made possible, which was decisive for the incremental multiplication of technical-cultural elements throughout time. ${ }^{77}$ Geertz's anthropological argument goes even further to crowd out the myth that culture only ensued in the human history after the evolutionary completion into Homo sapiens. As he remarked, elemental forms of proto-cultural activity, in the current view, seem to have been present since earlier stages of the human evolution - Australopithecines - , suggesting an overlap between cultural and biological processes. "What this means is that culture, rather than being added on, so to speak, to a finished or virtually finished animal, was ingredient, and centrally ingredient, in the production of that animal itself." 78 According to Geertz, the symbolic activity in which the human animal—or

\footnotetext{
${ }^{71}$ See generally Danilo Marcondes, As Armadilhas da Linguagem (2017).

${ }^{72}$ Karl-Heinz Ladeur, Die TeXtualität des Rechts-Zur poststrukturalistischen Kritik des Rechst 154 (2016).

${ }^{73}$ Eco, supra note 13 , at 42.

${ }^{74}$ Umberto Eco, Metaphor, Dictionary, and Encyclopedia, 15 NEW LiTERARY History 255 (1984).

${ }^{75}$ Umberto Eco, A Theory of Semiotics 28 (1977).

${ }^{76}$ See Clifford Geertz, The Interpretation of Cultures: Selected Essays 12-27 (Fontana Press 1993) (1973).

${ }^{77}$ Karl Eibl, Animal Poeta: Bausteine der biologischen Kultur- und Literaturtheorie 22 (2004) („bei der symbolisch-kommunikativen Kultur, ist auch der Platz für Geertz‘ Bild vom »Bedeutungsgewebe.« Erst mit der Sprache, genauer: mit dem Gegenstandsbezug der Sprache und mit der auf ihm aufbauenden Vergegenständlichung von Begriffen können kulturelle Vorräte-Informationen und Regeln — exosomatisch gespeichert werden, und das wiederum ist Voraussetzung für die kaskadierende (kumulative) Vermehrung von technisch-kulturellen Elementen über die Generationen hin.").

${ }^{78}$ Geertz, supra note 76 , at 47.
} 
the animal poeta in Eibl's depiction-engaged was determinant for his biological, technical and social evolution. The man created himself, so to speak, out of culture.

In the upshot, Geertz's cultural anthropology and Wittgenstein's pragmatic philosophy both converge on a cultural pragmatics for language and knowledge with clear implications for epistemology and philosophy of mind. Geertz's interworking relation between symbols and human development offers new theoretical inputs to be added into the mind-language philosophical puzzle in the sense that thinking is not an endogenous "mental activity" - a clear-cut biological activity segregated from the outside cultural semiosis; it rather resembles a "traffic" in the public avenue of symbols of a culture. Converging upon the central thesis that there is no thought or knowledge in a semiotic blank, Roy Harris' integrationist semiology-raised against the classical language myth - conceals a constructive theory of knowledge consonant with Geertz's cultural anthropology. For Harris, if every bit of knowledge takes place on the footing of an always contextualized sign or web of signs, ${ }^{79}$ then there is no context-free act of knowing, for every epistemic act presupposes a culturally-tailored semiotic apparatus. There is no process of knowledge outside "the-here-and-now" on which the knowing-subject finds himself.

When Wittgenstein rejected the idea of a private language by claiming that not only agreement in definitions but also agreement in judgments were required for communication by means of a language, ${ }^{80}$ he pointed at an underlying common knowledge implicit in the communicative network of a language. Apart from the collateral implications of what I have held so far, this last point brings a lot to bear on traditional epistemology - it calls for a social-laden sort of epistemological investigation, that is, a new account for knowledge ultimately grounded in social practices and cultural forms of life so as to encompass the common frames of intelligibility and practical repertoire historically accumulated in the cultural web of socially communicated practices that determine how we know what we know.

\section{Metaphors and cultural world}

As central mechanisms of natural languages, metaphors offer a valuable theoretical entry for new insights into how thoughts are structured in the common semiotic frames of a community of speech. Moreover, they reveal how we orient ourselves in terms of these structures, or how we organize and re-organize the common experiences of a form of life by creating and re-creating the categories of the social world. The philosophical discussion on metaphors, which I have neither the space nor the intention to deplete here, raises several points worthy of remark that not only feed back into the pragmatic philosophy of language and the philosophy of mind, but also reinforce a constructionist posture of the utmost importance for explaining institutional phenomena under the auspices of a cultural theory. When Charles Darwin claimed in On the Origin of Species that " $\mathrm{t}]$ he terms used by naturalists, of affinity, relationship, community of type, paternity, morphology, adaptive characters, rudimentary and aborted organs, etc., will cease to be metaphorical, and will have a plain signification," 81 a strict policy for scientific language was established, prescribing the banishment of metaphors from the scientific discourse. Being the common currency in natural languages, metaphors were locked out of analytical inspection by logical positivists and remained off the academic table until only a relatively recent revival in several fields of academia such as epistemology, philosophy of language, anthropology, linguistic theory, and semiotics.

\footnotetext{
${ }^{79}$ HARRIS, supra note 55, at 80 ("Just as every sign presupposes a context, every item of knowledge presupposes a context. There are no free-floating, contextless items of knowledge. There are no processes of knowing that exist independently of what is known. Knowledge, thus understood, is a form of activity.").

${ }^{80}$ WitTGenstein, supra note 33 , at $94 \mathrm{e}, \$ 242$.

${ }^{81}$ Charles Darwin, On the Origin of Species 443 (Gillian Beer ed., Oxford Univ. Press 2008) (1859).
} 
As Eco rightly remarked, every discourse on metaphor breaks out into a draconian choice: Either one accepts that language is metaphorical in its bent and every rule is set to control and impoverish the metaphorizing potential that distinguishes man as a symbolic animal (this view, taken to the extreme, is largely embraced by philosophers like Nietzsche); or language is originally a rule-governed system, a logical machinery for which a metaphor is a breakdown, a malfunction, or a scandal, ${ }^{82}$ as Darwin certainly thought to be case, and so did Bertrand Russell, Gottlob Frege, and the first Wittgenstein. The philosophical prejudice against metaphors is deeply related to the metaphysics of objective knowledge embraced by logic and natural sciences. As Hans Blumenberg brought to notice in his Paradigms for a Metaphorology, since at least the Cartesian Discours de la méthode, all forms and elements of figurative speech were downgraded to sheer makeshifts destined to be superseded by logic. ${ }^{83}$ Personally, I have no axe to grind on a metaphorological investigation, but I share in Blumenberg's goal of putting under the spotlight the logical perplexity displayed by metaphors and reconsidering the relationship between logic and imagination entailed by its use.

In the realms of philosophy and legal theory, the use of metaphors to treat hard topics is abundant in examples. To see language as a logical picture like the first Wittgenstein, or as a set of games like the second, or even as a social treasury like Umberto Eco, is to make use of metaphors as key theoretical devices of investigation. The same holds for law, which can be depicted either as a game-like activity such as chess, like Hart did, or as an interpretative social practice such as courtesy, like Dworkin, or even as an autopoietic system, like Niklas Luhmann. All these examples entail an imaginative use of well-known symbols garnered from the conceptual common pool of the Western culture to bridge a gap between what we know and what we are trying to grasp. As Aristotle already recognized in Rhetoric: Metaphors, most of all, produce knowledge. ${ }^{84}$

What is at issue here is the use of metaphors as creative tools for knowledge, as cognitive instruments. A metaphorical articulation of language unearths how we use a familiar conceptual apparatus to cast light on certain aspects of what we are trying to clutch and for which we still don't have a literal name. In this sense, Wittgenstein's "seeing as" intertwine with the conceptual proceedings of a metaphor in the sense that both entail the exercise of bringing to bear on what we are trying to grasp or see a ready-made conceptual support with a reinvented semantics. In this clash, a language insight shows through, leading to novel views on a domain of reference. Let us remember that Wittgenstein's "seeing as" is related to "the lighting up of an aspect," 85 something which is "half visual experience, half thought." 86 The "seeing" to which Wittgenstein refers is not, literally, the "seeing" provided by a conceptual metaphor (the view made possible by a metaphor is metaphorical in itself), but both proceedings show up the influence of background concepts, or background knowledge, in the process of coming to know something. In Wittgenstein's "seeing as" experience, "[w] hat forces itself on one is a concept," ${ }^{\text {" }}$ for in that case, "[o]nly someone conversant with the shapes of the two animals can 'see the duck-rabbit aspects."' 88

\footnotetext{
${ }^{82}$ Umberto Eco, Semiotics And the Philosophy of LANGuage 88 (1984) ("Every discourse on metaphor originates in a radical choice: either (a) language is by nature, and originally, metaphorical, and the mechanism of metaphor establishes linguistic activity, every rule or convention arising thereafter in order to discipline, to reduce (and impoverish) the metaphorizing potential that defines man as symbolic animal; or (b) language (and every other semiotic system) is a rule-governed mechanism, a predictive machine that says which phases can be generated and which not, and which from those able to be generated are 'good' or 'correct', or endowed with sense; a machine with regard to which the metaphor constitutes a breakdown, a malfunction, an unaccountable outcome, but at the same time the drive toward linguistic renewal.").

${ }^{83}$ Hans Blumenberg, Paradigms for a Metaphorology 2 (Robert Savage trans. 2010).

${ }^{84}$ Aristotle, Rhetoric 127 (C. D. C. Reeve trans., Hackett Publ'g Comp. 2018).

${ }^{85}$ WiTTGENSTEIN, supra note 33 , at $207 \mathrm{e}, \S 140$.

${ }^{86} I d$.

${ }^{87} I d$. at $215 \mathrm{e}, \$ 191$.

${ }^{88} I d$. at $217 \mathrm{e}, \S 216$.
} 
Metaphors are not language malpractice. They are a semiotic phenomenon, a common play of symbols in a form of life. To grasp a metaphor is to master a cultural language game. For Eco, the success of a metaphor is a function of the sociocultural format of the interpreting subjects' encyclopedia. ${ }^{89}$ Metaphors-whose mechanism resort to a "transfer", a "leap", or a "displacement" of meanings - unlock new ways of thinking. They instruct how to see cultural items in their social activity. ${ }^{90}$ The best metaphors, in his description, are those in which the cultural process of semiosis shows through. ${ }^{91}$ It is interesting that even a logic theorist like Searle confessed that metaphors are not amenable to be unpacked by formal logic. ${ }^{92}$ Eco also broached the logical impossibility of an algorithm for metaphors, for they fundamentally fall back on a semiotic decision of users contextualized in a cultural framework. ${ }^{93}$ Metaphors, at the most basic level, are engendered on the footing of a semiotic web mastered by local interpretants who collectively decide the semantic affinities, correlations, and distinctions.

By the same token, theorists like Lakoff and Johnson categorize metaphors as a cultural process of imaginative rationality. In Metaphors We Live By, Lakoff and Johnson mapped some metaphors deeply entrenched in modern Western culture, such as our agonistic conception of an argumentin ordinary phrases like "he shot down all of my arguments," "he attacked every weak point in my argument," and "your claims are indefensible" commodity-"you're wasting my time," "you're running out of time," "the flat tire cost me an hour," "you need to budget your time." 95 These metaphors structure our reality and how we act in the social world. They disclose how we conceive of a category in terms of another, or how we use language to organize our experiences of the world. The very notion of "interests"-a fundamental institution of market economies essentially based on the intertemporal rationality entailed in the exchange of goods and values - is firmly grounded in the structural metaphor of time as a negotiable commodity as it came to be socially naturalized in the Western industrialized society and underwritten by the market-oriented way of production.

The "seeing as" philosophical experience and the metaphorical mechanisms of language by which the social imagination plots upon reality, creating new spaces, new categories, new knowledge, and new forms of life, afford valuable entry points for a better understanding of our relationship with institutional constructs in cultural systems. The conceptual frameworks provided by our linguistic practices in all domains of life set for us certain capacities for aspectual perception which come into play every time we cope with the invisible ontology of the social world. The culture, the totality of language games in which we are trained, supply us with the subtlety and the skills to share broad assumptions and to make fine distinctions. ${ }^{96}$

\section{Towards a social epistemology}

\section{Contextualizing epistemology}

At first glance, a skeptical reader may have the impression that I am deliberately cooking a theoretical concoction to disguise an intractable philosophical deadlock by spotting several methodological aspects yet to be fairly exploited-anthropological, linguistic, semiotic, and epistemological. But I hope the scrupulous reader may bring a sharpened awareness to the

\footnotetext{
${ }^{89}$ ECO, supra note 82 , at 127.

${ }^{90} I d$. at 102 .

${ }^{91} I d$.

${ }^{92}$ JOHN SEARLE, INTENTIONALiTy 149 (1983).

${ }^{93} \mathrm{ECO}$, supra note 82 , at 127.

${ }^{94}$ George Lakoff \& Mark Johnson, Metaphors We Live By 4 (1980).

${ }^{95} \mathrm{Id}$. at 7-8.

${ }^{96}$ BARRY, supra note 41 , at 73 .
} 
common thread stitching across these lines. Assembling different methodological standpoints on offer, I have shed light on different facets of the same and fundamental problem.

Taking the integrational approach seriously, one may find very clearly the philosophical lineaments placed at the forefront of the whole enterprise: Knowledge is not a static-cognitive relation between a scientist wearing a white lab coat and an object under the microscope being examined inside of a laboratory completely isolated from the lifeworld. It is rather a semiotic activity that takes place on the footing of a communicational world wherein the knowing subjects find themselves always contextually engaged. The main criticism an integrational epistemologist could raise against an orthodox epistemologist who is still locked into the classic model of language is that the latter always thinks himself or herself to be operating in a semiotic and social vacuity. Because there is no private language with which one could reason in one's own terms, the integrational premise holds that every act of knowing presupposes a world of signs that environs the knower and provides him or her with the necessary and inescapable "relatedness" to the temporal dimensions of experience. A competent theory of knowledge, as Harris remarked, cannot dispense with the "intrinsic context" of knowledge. Context is the sine qua non of a sign and, by extension, of knowledge, for one could not conceive of an act of knowing in the absence of a public and historicized semiotic tissue. Signs invariably insert their users in a historical process of practices of use always already in progress. The knowing subject is always in medias res.

The integrational program comprises the methodology of a social epistemology with a semiological basis. It recognizes knowledge chiefly as a form of activity that hinges upon the forms of communication that are practiced in society. ${ }^{97}$ If forms of communication vary in time and space, then forms of knowledge, that is, ways of knowing, vary as well. As Roy Harris rightly remarked: "Different communicational worlds project different possibilities for knowledge because different semiological resources are available." 98 The invention of the writing and the recent technological advances in the West radically changed what we know and how we know it. The communicational world that we inhabit and the semiotic resources at our disposal form the determinant conditions for knowledge to break out. If we need signs to think, which was decisive for the evolution of men according to Geertz, then any epistemologist needs to be aware of the fact that signs don't fall from the sky nor can they be found in nature; signs are human creations with a history of meanings always inserted into a process of continuous transformation. Integrational epistemology states that practices of knowledge always presuppose an engagement of the self in a semiotic material that is publicly intelligible and always already social and historically situated. The acts of knowing, as well as the overarching process of knowledge, are contextual activities by their very nature. Contextuality is the keystone of an integrational theory of knowledge, the heart of social epistemology and cultural anthropology.

\section{Historicizing epistemology}

Despite the valuable inputs supplied by the integrational epistemology, I am still left with a certain theoretical uneasiness that Harris's integrationism failed to assuage satisfactorily. Although the emphasis was correctly shifted onto the semiological basis of knowledge and, by extension, to the contextuality that accompanies at all times each and every semiotic act of knowing - in which regard, I would not oppose a characterization of the integrational epistemology as a cultural or a semiotic theory of knowledge-, the social and historical aspects of knowledge, however implicit, were not minutely explored in Harris' After Epistemology.

In order to fill this gap, I shall seize on Hans-Jörg Rheinberger's insightful work, Historicizing Epistemology, to refine these points and to enhance my account of what knowledge is. In this connection, I will focus particularly on his perusal of two important contemporaneous thinkers

\footnotetext{
${ }^{97}$ HARRIS, supra note 55 , at 2 .

${ }^{98} I d$. at 87 .
} 
of the twentieth century who have made remarkable contributions for a program of historicized epistemology: The Polish physician and biologist Ludwick Fleck (1896-1961) and the French philosopher of science Gaston Bachelard (1884-1962).

Leaning on Rheinberger's analysis of the central pieces brought forth by these two theoreticians, an important connection immediately stands out: Both Fleck's and Gaston's accounts centered their theoretical endeavors on portraying the scientific activity predominantly as a collective enterprise. Bachelard pointed up the modern scientific work as a cooperative proceeding conducted and trammeled by internal negotiations of an epistemic community. ${ }^{99}$ By the same token, for Ludwick Fleck, a theory of knowledge cannot be reduced to a one-to-one subject-object relationship. It must take on, right from the very beginning, a social and cultural structure. ${ }^{100}$

An epistemologist and a philosopher of science cannot lose sight of the fact, as Bachelard accentuated it, that the process of production of scientific knowledge is always instrumentally mediated. It presupposes instruments, methods, and standard procedures, that is, protocols to abide by in order to attest to the objectivity of the experiment, which in turn were cooperatively and historically devised through a long process of retractions and breakthroughs-"epistemological breaks"101, as Bachelard put it. The metaphysical purity presupposed by traditional epistemology falls by the wayside in such schema, in which thought and reason (the internal) battle endlessly with experience and reality (the external) in the epistemological engagement between epistemic communities and objects of investigation.

Another social influence that indelibly encroaches upon the production of knowledge, according to Bachelard, is the fragmentation of fields in experimental sciences. Each experiment, under concrete contexts, paves the way for different microrationalities involving different sets of problems and material conditions with their own "epistemological awkwardness" 102 . This practical aspect of scientific knowledge was also emphasized by Ludwick Fleck, for whom there is a way of producing scientific knowledge that cannot be drawn directly from books, for it can only be mastered in the day-to-day practices of scientific experiments conducted in a laboratory. ${ }^{103}$ For both Bachelard and Fleck, the relationship between subjects and object is not analytic or contemplative, but rather synthetic and constructive. ${ }^{104}$ It presupposes an entanglement of the subject in the experiment.

Ludwig Fleck also laid fair emphasis on how social elements set their seal on knowledge. On Fleck's account, the process of knowledge production is fundamentally a social process. It necessarily involves a community of experts in constant intellectual interaction-a condition of knowledge which he termed "thought collective"105. At bottom, both Fleck's and Bachelard's depiction of knowledge reaffirms, counter to the traditional epistemology grounded in metaphysical realism, that: (a) firstly, knowledge should not be taken as a state of affairs; rather, it should be visualized and probed as a social and historical process shared by different types of scientific communities and in different contexts of scientific practice. Knowledge is always bound up with a previous "history of knowing"106 (Wissensgeschichte); (b) secondly, the process of knowledge has, at all stages, a collective authorship. In other words, it is never the product of reason of a single individuum, but a diachronic product of an engagement between experiences and thought processes of several people interacting across different historical contexts.

The historicist model of knowledge broadly outlined by Fleck and Bachelard, if rightly understood, ultimately outflanks the main philosophical doctrines that backdrop the traditional model.

\footnotetext{
${ }^{99}$ Hans-Jörg Rheinberger, On Historicizing Epistemology: An Essay 24 (David Fernbach trans., 2010).

${ }^{100} I d$. at 28 .

${ }^{101} I d$. at 22 .

${ }^{102} I d$. at 24 .

${ }^{103} I d$. at 29 .

${ }^{104} \mathrm{Id}$.

${ }^{105} I d$. at 31 .

${ }^{106} I d$. at 32 .
} 
Knowledge doesn't come down to a system of logical propositions nor can it be reduced to a sheer reflection of the external world bereft of any human contribution. It rather lies, as Harris' integrational epistemology rightly emphasized, exactly in the engagement of the subject in contextual reality. The self of the epistemic subject cannot be suspended in the act of knowing, just like the reader cannot be suppressed in the act of reading. ${ }^{107}$

If the Cartesian project of reaching an "absolute conception" 108 of reality-a conception that is thoroughly independent of our experiences and our minds-marked an ineradicable habit of thought in the history of epistemology, a sharp awareness of the historical, social, practical, and semiotic aspects entangled in the process of knowledge indicates how Descartes' Archimedean point is nothing short of a philosophical idol. The Cartesian "Pure Enquirer," even if possible, in the real world, could not find his feet with the human condition, for our knowledge presupposes, at all stages of development, a historical process, a semiotic media, and a community of users engaged in communicative practices. Knowledge is not of "what is there anyway" 109 nor is it a "view from nowhere". ${ }^{110}$ If I am on the right lines with an integrationist and historicized epistemology, then knowledge is not about gaining epistemic access to something lying outside; it takes place inside ourselves and through a semiotic apparatus historically produced by human beings interacting with each other in several different contextual frames of communication. ${ }^{111}$

\section{Personalizing epistemology}

Whenever we do, think, or say something, we are never at the beginning of things, "we are always already in the midst of things." 112 The objectivist urge to annul the human coefficient in the process of knowledge - the idolatry of an "impersonal thought"113 or a "mindless knower," Polanyi's terms - seems to be a self-nullifying enterprise of the human mind, pointless attempts to depersonalize knowledge. Polanyi's theory of personal knowledge essentially subscribes to the semiological basis or the cultural format of knowledge the same way as an integrationist considers "knowledge without the self"-depersonalized knowledge-a pretentious nonsense. ${ }^{115}$ In contradistinction to the metaphysics of objectivism or an "epistemology without a knowing subject", Polanyi's epistemological methodology devotes serious attention to the perception of knowledge as fundamentally dependent on human language and human intercourse. As he rightly remarked:

Tacit assent and intellectual passions, the sharing of an idiom and of a cultural heritage, affiliation to a like-minded community: such are the impulses which shape our vision of the nature of things on which we rely for our mastery of things. No intelligence, however critical or original, can operate outside such a fiduciary framework. ${ }^{116}$

Both Harris' integrational epistemology and Polanyi's personal knowledge theory concur in the anti-Cartesian view that the human coefficient, rather than being an imperfection in the art of knowing, is exactly the vital component of knowledge. Both accounts share in the common undertaking of blurring the lines which years of skeptical philosophy strived to draw between objectivity and subjectivity. Another common feature of which both epistemologies partake is the

\footnotetext{
${ }^{107}$ HARRIS, supra note 55 , at 102.

${ }^{108}$ See Bernard Williams, Descartes: The Project of Pure Enquiry 48 et seq. (Routledge 2005).

${ }^{109} I d$. at 48 .

${ }^{110}$ See generally Thomas Nagel, The VIEW From Nowhere (1986).

${ }^{111}$ HARRIS, supra note 55, at 162.

${ }^{112}$ Rheinberger, supra note 99, at 28.

${ }^{113}$ Michael Polanyi, Personal Knowledge: Towards a Post-Critical Philosophy 257 (1998).

${ }^{114} \mathrm{Id}$. at 264 .

${ }^{115}$ HARRIS, supra note 55, at 128.

${ }^{116}$ POLANYI, supra note 113 , at 266.
} 
understanding of knowledge as both practical and theoretical. If, on the one hand, Harris sees knowledge chiefly as a form of activity that is to be found in practices such as music and painting, Polanyi's conception of knowledge, on the other hand, also involves an active posture of the knowing subject. The "knowing what" and the "knowing how"- the theoretical and the practical-are both aspects of knowledge and both display a similar structure. ${ }^{117}$

I want to briefly flesh out these two aspects entangled in Polanyi's main anti-Cartesian theses: (a) The relation between objectivity and subjectivity; (b) the conceptual conciliation between knowledge-what and knowledge-how. On the first point, the silver bullet lurked under the concept of "personal knowledge," which I shall lean on, is the affirmance that knowledge can only be considered from the human perspective. Contrary to Popper's claim that knowledge, at least in the objective sense, is totally independent of anybody's claim to know, even his own-"knowledge without a knower"118_Polanyi's "personal" approach flags up symmetrically the opposite: Knowledge is a condition of men, not of gods. The art of knowing is an activity that takes place in the lifeworld of our experiences. The "personal" of Polanyi, in the upshot, throws the pendulum of knowledge back to the human perspective across from the objectivist ideal.

The second point I want to foreground relates to the tacit dimension of knowledge, on which Polanyi lengthily expounds in The Tacit Dimension. The main thesis_-"we can know more than we can tell"119 - touches exactly on the sore point of epistemology: The type of knowledge which can never be made fully explicit. The main reason why knowledge-how seems to have been an irking theme for rationalist epistemologists is that it cannot be gauged, as it were, by a set of logical propositions; it does not "fit," so to speak, a verbal report. There is, of course, a remarkable distinction between know-what and know-how, but what philosophers have chiefly downgraded is how intricate is their relationship. Gilbert Ryle and Michael Polanyi, among a few others, comprise the select group of theoreticians who have paid fair attention to that matter.

It is not my intent to unpack all the specifics embedded in Polanyi's tacit dimension, as it involves, I suppose, much more than just a practical and inexpressible element at the back of every act of knowing, but I shall at least trace some connections between Polanyi and Ryle with regard to the inexpressible content presupposed in every bit of knowledge. And the first claim I will bring out calls into question the fundamental assumptions about knowledge chiefly assumed by logical analysts. When the mathematicians are faced with a hard problem, they know that their theoretical knowledge will not suffice to guarantee the solution. They will have to resort to a technical skill, a practical intelligence to apply their mathematical knowledge to the solution of the problem. And not just that: Every trained mathematician knows that hard problems demand a "personal" engagement of the self to determine the most elegant, simple, and economical way out of them.

This kind of intelligence is very different in nature from the sheer knowledge of several mathematical theorems that can be combined and applied to the creative solution of the problem. As Ryle argued, there is a gulf between the acknowledgment of rational principles in thought and their intelligent application in action. ${ }^{120}$ It is in the vain of this gulf that one may find an entry point to the tacit and personal dimension of knowledge in Polanyi's sense. As he remarked: “This is why mathematical theory can be learned only by practicing its application: Its true knowledge lies in our ability to use it." 121 That is, mathematical knowledge involves knowing how to use theorems, methods, and logical rules in such a way that cannot be entirely expressed or stated beforehand, though it might be acquired by means of work experience in the same way as a wine connoisseur acquires an ability to perceive and distinguish tastes in a way that cannot be verbally expressed.

\footnotetext{
${ }^{117}$ Michael Polanyi, (2009). The Tacit Dimension 7 (2009).

${ }^{118}$ POPPER, supra note 22 , at 109.

${ }^{119} I d$. at 4 .

${ }^{120}$ Gilbert Ryle, Knowing How and Knowing That, in LOGIC LANE, supra note 46, at 228.

${ }^{121}$ POLANYI, supra note 117 , at 17.
} 
The same holds true for scientific knowledge, as advocated by Fleck and Bachelard ${ }^{122}$. There are, in every scientific research, personal and tacit elements which any scientist cannot dispense with: An initial hunch, the choice of the topic, the choice of the methods, laboratory experience, and the interpretation of the results. In all these stages, a personal engagement and a practical intelligence are inevitably implied. A scientist, argues Ryle, is primarily a knower-how and only secondarily a knower-what, for one could not discover any particular truths unless one knew in advance how to conduct a research, how to proceed, and how to discover. ${ }^{123}$ In a nutshell: "The advance of knowledge does not consist only in the accumulation of discovered truths, but also and chiefly in the cumulative mastery of methods." 124

There are all sorts of examples of practical knowledge on offer in the human experience: The chess players who acquire, through time and practice, the ability to outmaneuver their opponent at unforeseeable situations, or Backer's and Hacker's example of the pianist who can play Bach and Chopin trills with the tacit knowledge that the former is to begin above the printed note and the latter on the printed note, even though when asked, that's not his or her answer, but when told the answer, he or she is able to recognize it as the correct one. ${ }^{125}$ And, of course, the same goes for the novelist, the poet, the engineer, the physician, the lawyer, etc. In every human endeavor, there is an intelligence, as Ryle observed it, that is exhibited by deeds, not by dicta. ${ }^{126}$

\section{Law}

\section{Which analysis?}

I have stated at the very beginning that only after Sections B and C of my paper, so imbued with the right angle on both language and knowledge-which I've done by resorting to Wittgenstein's philosophy of language, Geertz's cultural anthropology, Eco's semiotics, Harris' integrationalism, Bachelard, Fleck, Polanyi, and others-I would then have reached a firm stand to reassess the conceptual problem of law initially canvassed along the lines of a methodological route which I deemed to be the most suitable for an adequate treatment of fine conceptual issues of law. In this connection, I align myself with those legal theorists, like Brian Leiter, who have decried the excessive analyticity of the current anglophone methodological debate over the concept of law, urging "jurisprudence to get up from the armchair and find out what anthropologists, sociologists, psychologists, and others can tell us about the social practices in and around law."127

Hart's analytical project of designing a theory of law detached from any particular legal system or legal culture, as he intimated in the postscript, doesn't seem to afford a good hold in facts at which one could clutch. To use one example from Rosen's vast anthropological catalog, the relation between law and morals, intensely discussed among analytical theorists in aprioristic terms, received a concrete approach in his Law as Culture. One of Rosen's examples is the Tiruray, a social group in the Philippines who believes that men are naturally prone to violence. On this account, if a man is injured in some sense, he should be addressed cautiously; as a result, the members of that group developed throughout time, in Rosen's words, "a refined sense of appropriate conduct as well as personal sensibility." ${ }^{28}$ This cultural framework-along with the fact that they do not believe that a final decision in binary terms (right and wrong) ever really ends a dispute-incrementally produced a style of legal-mindedness centered around "the delicate

\footnotetext{
${ }^{122}$ See generally RHEINBERGER, supra note 99.

${ }^{123}$ Ryle, supra note 120 , at 235.

${ }^{124} I d$. at 234 .

${ }^{125}$ HACKER \& BAKER, supra note 42 , at 341.

${ }^{126}$ Ryle, supra note 120 , at 228 .

${ }^{127}$ Brian Leiter, Legal Realism, Hard Positivism, and the Limits of Conceptual Analysis, in HART'S POSTSCRIPT: ESSAYS ON THE Postscript to The CONCEPT OF LAw 369 (Jules Coleman ed., 2d ed. 2001).

${ }^{128}$ Rosen, supra note 4 , at 24 .
} 
interplay of personal discomfort and moral principles that can express and momentarily articulate the bases for continued interaction." 129 The Tiruray is an anthropological example of a recalcitrant experience against any conceptual proposition that holds a strict demarcation between law and morality.

But if Hart claims that there are no necessary conceptual connections between law and morality-or any other external sphere, such as politics or economy-a cultural analysis of the Tiruray, such as Rosen's, unearths precisely the hidden conceptual relatedness through which the broader conceptual framework of a culture supplies law with meaning. As Rosen argues, in any legal system, the articulation of a broad standard-"human dignity" or "honor" in the German Constitution; or in the United States' legislation, the protection against "unconscionable" contractual clauses according to the Uniform Commercial Code ${ }^{130}$ —is usually suffused with cultural contents that lend legitimacy and meaning to any of its legal application. ${ }^{131}$ Many of the pivotal precepts of a legal scheme are, in accord with Rosen's repertoire of concrete examples, structurally bound up with cultural constructs that render them meaningful and intelligible.

In contradistinction to analytical inquiries, I would rather avail myself of Harris' integrational thrust in line with Rosen's cultural analysis fundamentally grounded in legal anthropology. If an integrational view would regard the very nature of law as being at stake in the legal conflicts and processes themselves, ${ }^{132}$ thwarting any analytical anchorage for the concept of law, Rosen's take on Law as Culture raises the central methodological argument that the events of law and life do not exist in abstract, but in concrete patterns of everyday experience, ${ }^{133}$ precisely where law should be analyzed: i.e. In concrete and comparative examples. Rosen's cultural analysis suggests, as I have outlined in the introduction, that law is so deeply rooted in culture and culture so extensively constituted by law that a complete analysis of one cannot afford to lose sight of the other.

Another connection which is worth sorting out between Rosen's cultural analysis and an integrational view of law is that both approaches mistrust and take issues with a clear-cut line or sharp contrast between ordinary talk and legal language as any sophisticated version of legal positivism would sustain. Hard positivism would claim an unbreakable line of division between the two. In comparison, incorporative or inclusive legal positivism, such as Hart's, would hold that such line is bound to be ultimately decided by a rule of recognition that determines if and which contents from the ordinary semantics should be endowed with authoritative recognition in the legal system-on the footing of rational criteria which are agreed upon by the community of officials in law-applying and law-enforcing procedures.

What is at stake here is how autonomous the law-talk really is, or to put it faintly differently: Where it lies, if it does somewhere, the boundaries between ordinary language and legal language? The question may slide into slightly different terms with an eye to the same problem: Is there a sharp contrast between formal and informal institutions? Lawrence Rosen frames the issue by raising an argument based on legitimacy: "[H] ow can a legal system be said to possess legitimacy if a large part of the population subject to its processes and assumptions does not possess the same basis for accepting its legitimacy?" 134 In the face of these questions, as Rosen well noticed, words like "indeterminacy" and "open texture," so current in philosophical discussions, began to crop up in legal discussions.

Taking this cue, what Hart sustained in The Concept of Law under the heading The Open Texture of Law is that the relative indeterminacy of rules can be at least curbed once the issue

\footnotetext{
${ }^{129} \mathrm{Id}$. at 24.

${ }^{130} \mathrm{Id}$. at 30 .

${ }^{131} I$ d. at 32 .

${ }^{132}$ Roy Harris \& Christopher Hutton, Definition in Theory and Practice: Language, Lexicography and the LAW 141 (2007).

${ }^{133}$ Rosen, supra note 4 , at xiii (preface).

${ }^{134} \mathrm{Id}$. at 127 .
} 
is put in the light of the social aims involved. ${ }^{135}$ But what Hart was not able to reach is exactly what a cultural theory based on an ample inventory of anthropological examples suggests: Not only the social aims encroach upon the constitutive practices of law, but also the whole cultural encyclopedia of concepts that bounds the multiple spheres of social practices comes into play as a supporting structure for the legal rule.

By the same token, an integrational take on law equally debunks a sharp contrast between ordinary usage and legal language. Harris' main integrational argument is that the nature of the problems that arise in the open texture of law are of the same kind as those that arise in the human communication of ordinary social life in general: "An integrational view of law would suggest that law can never coalesce into an organic whole, just as to regard human language or languages as an organic structure is deeply misleading when set against the often scrappy and contentious nature of human interaction." "36 The principal point of dissent from Hart's theory, raised by Harris in common with Rosen's cultural theory, is its excessive reliance on the "core of certainty" that legal language is taken to be invested with.

If it is true that Harris deems Hart's analytic differentiation between the core of certainty and the penumbra of uncertainty to be an ambivalent position both in accord-on the core of certainty's side — and disaccord-on the penumbra of uncertainty's side—with a fixed-code model of language, and suggests that law, as social life in general, is not built upon an unproblematic consensus, ${ }^{137}$ Rosen, in parallel, touches upon the same critical spot by taking part in the question of how can we consider culture simply as "shared symbols" "when individuals quite obviously read different meanings into every social and legal concept imaginable."138 Insofar as law does not create facts in complete isolation, legal concepts inevitably fall back at some point on what is itself unlawful, on the wide cultural net of concepts, as a matter of greater coherence and legitimacy for the legal system.

The tight connection interlocking law and culture flows over the edges of the relation between legal concepts and ordinary meanings and impinges on the reasoning styles that demarcate continental lawyers from common lawyers. As Rosen sums up, if facts in European systems are brought under a wide range of legal categories, common lawyers usually proceed reversely, drawing legal categories from concrete instances, rather than deriving instances from previously defined categories. ${ }^{139}$ The differences naturally resort to broader cultural orientations that far exceed law itself: On the one hand, "the European history of securing the individual against the depredations of the state by raising state institutions to a level of impersonality and 'scientific' truth, and then protecting the individual through law as an arm of that state"; ${ }^{140}$ on the other hand, "the emphasis on 'practicality' as a surer test of worth than being true to form, and the elaboration of the idea that change-whether dangerous or beneficial-comes largely from the eccentric."141

All these differences as to the varying conceptual performances of law I have been pointing out cannot be settled in terms of truth. There is no better way of reasoning-between the continental and the common styles-just as there is no fixed point of meaning in the natural development of legal concepts at which one could anchor his or her analytical certainty. Neither metaphysical claims - as of natural lawyers-nor analytical claims about legal meanings seem to best suit not only how legal language, but also how language in general works. There are, at least for the majority of relevant concepts sensitive to social interaction, only naturalized and ephemeral forms open to dispute and in reaction to the social and historical demands in the larger cultural process to which they are attached.

\footnotetext{
${ }^{135}$ HART, supra note 28 , at 130.

${ }^{136}$ HARRIS \& HUTTON, supra note 132, at 146.

${ }^{137} \mathrm{Id}$. at 146 .

${ }^{138}$ Rosen, supra note 4 , at 127.

${ }^{139} \mathrm{Id}$. at 142 .

${ }^{140} I d$.

${ }^{141} I d$. at $142-43$.
} 


\section{Which knowledge?}

As I have already mentioned, the initial problem from which I have set out was the misconception embraced by some legal theorists that law can be dealt with in terms of logical constructs, such that it may be shifted from culture to culture and still work in the same way. My goal has been to point out the philosophical myths behind that conception of law, both in the philosophy of language and the epistemology, and raise a theoretical argument that can be unpacked into these two components - the first concerning language; and the second, strongly intertwined with the first, regarding knowledge.

In respect of the first, the chief philosophical error at the root of legal transplants, which I have endeavored to expose with fair clarity in the course of Section B, may be summarized in Harris' portrayal of "the classical model of language." That is, for legal transplants to work, language must be supposed to function as a fixed code, a logical system of signs that can be "injected" into other communities of legal practice and "learned" at a stroke by local practitioners. Proponents of legal transfers, I shall call them simply "fixed-code theorists" (faute the miex) are necessarily committed to the telementational conception of language. The idea that certain legal institution verbally framed may be exported to another culture and touch off similar interpretations and conceptual performances reflects, at its core, as Michael Toolan put it, "a faith in words as carriers of meanings, and of meanings as stable and detachable from those words." ${ }^{42}$ This epistemic misconception apropos of verbally framed rules has been called, in legal theory, formalism or conceptualism. ${ }^{143}$ The jurists' "heaven of concepts," as Hart remarked, is reached "when a general term is given the same meaning not only in every application of a single rule, but whenever it appears in any rule in the legal system." 144

What we must take heed of is that the linguistic workings of law do not take place in a social and historical vacuum; they go hand in hand with constitutive processes of social structures of practices that underlie the conceptual functioning of textualized legal norms. Just like the rules of rhyming and prosody do not tell me what a poem told me, ${ }^{145}$ law cannot be mastered by mere acquaintance with its conceptual vocabulary; it can only be thoroughly grasped within the living social context in which it is put into practice, each case resorting to "a practical world of meanings as well as to an implicit, familiar significance in the 'here and now' of a linguistic community." 146

The modern portrayal of law has always aspired to divest legal semantics of cultural semantics. Kelsen's postulation of a logic-transcendent meta-norm to shore up an inner-grounded validity for the law, uprooted from its social grounds, wasn't enough to flout the relation of dependence between the signals of legal validity and social efficacy. ${ }^{147}$ As Vesting well remarked, the validity of a legal norm isn't dependent, as Kelsen wanted, on a minimum of efficacy. Just the opposite: For the formation of the law, it is necessary a maximum formation of successful conventions in practice. ${ }^{148}$ For even if the establishment of a semantic relation by means of a semiotic mark may begin with an act of will, its acceptance, its social efficacy, and its mode of existence will hinge on frames of meanings engendered in social experiences and the social practice of being invoked in the course of a rule-governed activity.

Once we reattach the concept of law to the concrete processes where it is being used and applied by local lawyers and common people in concrete scenarios of social interaction to the continuum of creative activity and social imagination by force of which the concept itself is

\footnotetext{
${ }^{142}$ Michael Toolan, The Language Myth and the Law, in The Language Myth In Western Culture 162 (Roy Harris ed., 2013)

${ }^{143}$ HART, supra note 28 , at $129-30$.

${ }^{144} I d$. at 130 .

${ }^{145}$ POLANYI, supra note 117 , at 20.

${ }^{146}$ Vesting, supra note 7 , at 16.

${ }^{147}$ Hans Kelsen, General Theory of Law and State 42 (Anders Wedberg trans. 2007).

${ }^{148}$ VESTING, supra note 23 , at 115.
} 
swayed, we thus seem to approximate to the conception of law as a capacious storehouse of stories, ${ }^{149}$ as Rosen put it, and start to understand it in the context of local narratives that give it meaning, ${ }^{150}$ as Robert Cover implied in the famous article Nomos and Narrative. If I am on the right lines, this reconceptualization leads us, by the same token, to new insights into the conception of legal knowledge as a form of local knowledge. If there is no such thing as private language, and knowledge, as I sustained in Section C of this text, is a form of activity that takes place on the footing of a communicational world fundamentally structured in a tissue of public signs, then it is precisely by such lights that we should reassess the phenomenon of legal knowledge.

The integrational epistemology, based on an integrational semiology - in the sense that signs do not hold independently of their integration into the particular activities and cultural contexts in which they are used-assures us that there are no free-floating, contextless items of knowledge. ${ }^{151}$ Just like Geertz's cultural anthropology suggests that the homo sapiens' brain is not a endogenously driven and context-independent system and that culture and mind coevolved interdependently, ${ }^{152}$ so proceeds Rosen's cultural-anthropological theory of law: "If thought is carried by symbols, it becomes possible to unpack the structure of these symbolic forms and get at the ways in which collective ideas and actions are oriented." 153 The unpacking of these symbolic forms to which Rosen refers is the target of an ethnographic interpretation of the symbolic components embedded in the social discourse and social practices of a culture in the sense meant by Geertz, to which I alluded in the final part of the first Section: Words, images, customs, rites, and stories, which are not vehicles of meanings, reflections, or feelings lodged elsewhere, "but [are] the locus and the machinery of the thing itself." ${ }^{\text {" }}$.

Given this indistinct line between mind and culture, I am led to conclude that legal knowledge must be approached in terms of local knowledge. That is, legal epistemology is only possible as local epistemology: "Like sailing, gardening, politics, and poetry, law and ethnography are crafts of place: [T] hey work by the lights of local knowledge" ${ }^{155}$. In this connection, I must recall the close tie-in between "the local" and "the tacit" dimensions of knowledge to which I referred under the topic "Personalizing epistemology" in Section C of this text. Polanyi's Personal Knowledge associates the tacit dimension with the sharing of an idiom, the cultural heritage, and the affiliation to a like-minded community; thus, it blurs the boundaries between "knowing what" and "knowing how. "

The law's connections with local components creep into the practice of law in several relevant aspects. They include how legal texts are argumentatively used, how local facts are addressed, and how the conceptual gap between the written format of legal texts and concrete cases is bridged. Like the mathematician who needs not only to have the knowledge of theorems, methods, and logical rules, but also to know how to apply his theoretical repertoire to the most economical solution of a mathematical problem, the lawyer needs not only to have knowledge of legal texts, doctrine, and precedents, but also to know how his legal and general culture work in order to apply his knowledge of legal statues, precedents, and interpretative methods to the most appropriate solution of a case in line with cultural rules of signification.

\section{E. Conclusive remarks}

In outline, I shall condense the main theses advocated in this text in a reasonable concatenation of premises, arguments, and conclusions:

\footnotetext{
${ }^{149}$ Rosen, supra note 4 , at xii (preface).

${ }^{150}$ Robert Cover, Foreword: Nomos and Narrative, 97 HaRV. L. REv. 4, 5 (1983).

${ }^{151}$ HARRIS, supra note 55 , at 80.

${ }^{152}$ Clifford Geertz, Available Light: Anthropological Reflections on Philosophical Topics 150 (2001).

${ }^{153}$ Rosen, supra note 4 , at 126.

${ }^{154}$ GEERTZ, supra note 152 , at 152.

${ }^{155}$ Clifford Geertz, Local Knowledge: Further Essays in Interpretative Anthropology 167 (2000).
} 
I. Legal transplants are bound to be unsuccessful, for they convey an erroneous conception of law, language, and legal knowledge. Once legal institutions are decoupled from their cultural background and resettled in different social emplacements (e.g., the transplantation of the continental principle of bona fides into British contract law, exemplified by Gunther Teubner), their intertextuality to the diffuse web of local practices will likely beget fundamental changes in their conceptual grammar. They will be used according to different criteria, i.e. different cultural rules of signification.

II. The core of the misconception involving legal transplants is the ingenuous expectation that the shifting of legal institutions will haul along with them the whole background of conceptual practices historically developed in their original soil. Behind the idea of legal transplants lurks the misleading assumption that two different legal cultures share a common concept of law and common epistemological accounts of what is meant by law.

III. My goal has been to expose the philosophical backdrop that lies behind the conception of law implied in the idea of a legal transplant with an eye to the cultural perspective. To this end, I have availed myself of different but convergent perspectives gathered from the philosophy of language, cultural anthropology, semiology, epistemology, and legal theory, as a methodological strategy to spotlight different facets of the problem in three dimensions-language, knowledge, and law.

IV. Regarding language, the chief philosophical misconception at the root of legal transplants may be summarized in Harris' portrayal of the classical model of language. For legal transplants to work, language must be supposed to function as a fixed code-a logical system of signs that can be "injected" into other communities of legal practice and "learned" at a stroke by local practitioners. Proponents of legal transplants are necessarily committed to the telementational conception of language. The idea that certain legal institution verbally framed may be exported to another culture and touch off similar interpretations and conceptual performances reflects, at its core, as Michael Toolan put it, "a faith in words as carriers of meanings, and of meanings as stable and detachable from those words." 156

V. Legal transplants presuppose law as a systemic array of objective meanings rationally determined and logically derived from legal texts through a context-independent epistemic process.

VI. The pragmatics of language implies in the last resort the pragmatics of knowledge itself, as I have tried to establish resorting to Wittgenstein's pragmatic philosophy of language, Harris' integrationism, and Geertz's cultural anthropology. Knowledge is collectively engendered, historically constructed, and contextual all the way, through and through. Once we discharge the concept of law from metaphysical trammels and analytical footholds and reattach it to concrete cultural processes by which it is swayed, we are led to the understanding of legal knowledge as local knowledge. Legal epistemology is only possible as local epistemology.

\footnotetext{
${ }^{156}$ Toolan, supra note 142 , at 162.
} 